\title{
Carl Buchheit, Ellie Schamber, Transformational NLP: A New Psychology, Ashland, White Cloud Press, 2017, 232 p.
}

Transformational NLP: A New Psychology reprezintă un volum apologetic al Mișcării de dezvoltare a potențialului uman, având ca autori pe Ph.D. Carl Buchheit și Ph.D. Ellie

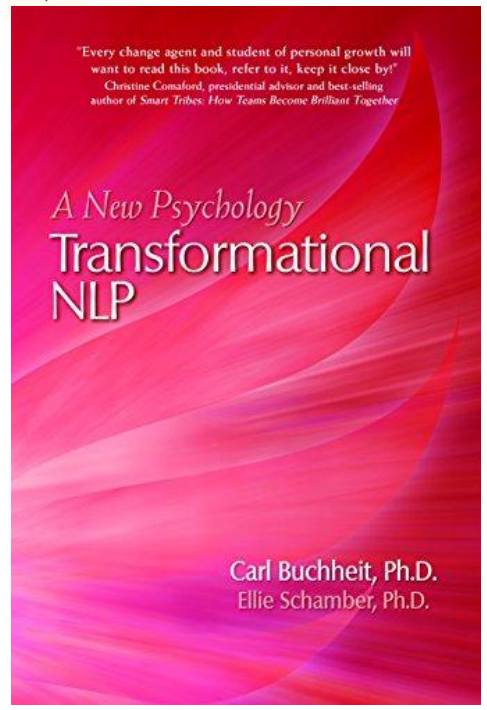

Schamber. Această lucrare a apărut în anul 2017, în regiunea americană Ashland din Oregon, fiind tipărită de către editura White Cloud Press și însumează un număr de 232 pagini.

Acest studiu promite să ofere un răspuns tuturor oamenilor secolului al XXI-lea. Autorii se adresează în special celor care caută un sens, un răspuns profund, următoarelor întrebări: De ce oamenii au atât de multe dificultăți în a-și atinge obiectivele, în a face schimbări majore și în a deveni oamenii care își doresc să fie?

Dacă ne putem imagina, de ce nu putem și realiza?

Programarea neuro-lingvistică transformațională oferă o nouă înțelegere a modului în care funcționează cu adevărat creierul 
uman. Această ,știință” susține că ajută pe noul iniţiat să înțeleagă cum funcționează şi cum poate canaliza întreaga potență a creierului. Acesta poate învăţa rapid cum să își canalizeze puterea neuronală încât aceasta să lucreze cu el și nu împotriva lui.

În paginile acestei cărți este promisă schimbarea, o schimbare care devine imediat posibilă și uşor realizabilă. NLP transformațional este o sinteză revoluționară a programării neurolingvistice (NLP), a psihologiei și a spiritualităţii. Se regăsesc felurite exerciții în această carte, o practică similară psihoterapiei, dar care folosește instrumentele NLP, precum și anumitele inovaţii extrase din fizica cuantică, neuroștiință, psihologie și constelații sistemice.

În Transformational NLP, Carl Buchheit promite o nouă metodologie pentru ca iniţiatul să poată atinge obiectivele de transformare personală și de fericire, de care acesta nu era pe deplin conștient. Este prezentată o nouă psihologie, un nou sistem de gândire, ce oferă o nouă înțelegere a modului în care funcționează într-adevăr omul. Acest fel de gândire, dacă este pus în practică, descoperă practicantului modul în care poate folosi cunoștințele specifice NLP-ului pentru schimbarea și creșterea personală.

NLP transformațional încorporează material extras din sau inspirat din modelul holografic al universului, așa cum a explicat fizicianul David Bohm, premisele și implicațiile de bază ale mecanicii cuantice din secolele al XX-lea și al XXI-lea, lucrările de constelaţie transgeneraționale, sistemice, ale lui Bert Hellinger și metafizica filosofiei perene, precum cea descrisă de Aldous Huxley. Oferă cunoștințe avansate și metode unice atât neurolingvistice, cât și altele, pe care Buchheit le-a dezvoltat de-a lungul a peste trei decenii, lucrând cu mii de cursanți. Această carte se prezintă ca fiind de mare interes pentru toți studenții din NLP, precum și pentru psihologi, asistenți sociali, lucrători în sănătate mintală, profesori, istorici și filosofi. Poate atrage în special atenția celor care sunt interesați de transformarea personală și de a obține perspective complet noi despre înțelegerea și schimbarea experienței umane. 
Recenzie: Carl Buchheit, Eliie Schamber,

Transformational NLP: A New Psychology

O practică interesantă prezentă în acest volum este cea de asumare a greșelilor, a „,ancorelor”, prin recunoașterea lor publică. Această practică are trei etape și anume: rostirea greșelii în faţa oglinzii, rostirea greșelii în fața inițiatorului, rostirea greșelii în fața mai multor persoane. Se atribuie acestei practici o conotaţie atât psihologică, cât și spirituală, asemănându-se destul de mult cu Taina Sfintei Spovedanii. NLP-ul reprezintă un fenomen complex pentru studiu, deoarece acesta reușește să se metamorfozeze cu succes dintr-o simplă practică de auto-educare la o ideologie profundă ce tinde a se extinde peste hotarele disciplinelor de comunicare, ajungând până la nivelul de a se identifica drept o mișcare cu caracter spiritual, dând dovadă de elemente terapeutice, atât fizice, cât și metafizice.

Citate reprezentative din cadrul volumului:

„Descoperirile despre modul în care spiritul, mintea și corpul pot fi aduse într-o singură conlucrare, deschid calea către propriul sine, devenind cine vrem cu adevărat să fim și să lucrăm unii cu alții cu o nouă profunzime și cu respect pentru experiența de a fi om" (p. 4).

„Am petrecut mai multe zeci de ani încercând să adaptez N.L.P.-ul pentru a putea să fie întrebuințat în domeniul metafizic și spiritual. Pentru mine, unul dintre cele mai bune lucruri despre N.L.P.-ul transformațional este capacitatea de a face obiectul metafizicii şi spiritualităţii profunde relevant direct pentru operațiunile creierului nostru local” (p. 14).

„Învățăturile și magia vindecătoare reprezintă asigurarea faptului că noi deținem conștientizarea totală a naturii și a scopului nostru adevărat, combinată cu instrumentele necesare pentru a elimina rezistența la durerea dobândită. Această practică oferă un acces solid și uşor la uimitoarele metode care ne permit să ajungem la o experiență viitoare mult mai bună, fără a fi nevoie să ne învinuim pe noi înşine sau pe oricine sau orice altceva" (p. 21).

„Nu se poate realiza o separaţie a observatorului de sistem, ci este posibilă numai schimbarea stărilor și a credinței interioare, pentru a se putea influența alți indivizi, iar prin ei, societatea în general și chiar universul în sine. Se explică de asemenea că, la fel 
ca și în fizica cuantică, tot felul de șiruri și căi există prin spațiutimp, cu scopul de a lega trecutul de viitor" (p. 21).

În final, menționăm câteva date despre autori: Carl Buchheit este doctor în psihologie transpersonală la Universitatea Internațională de Studii Profesionale. Carl a început să studieze programarea neuro-lingvistică în 1979. Cariera sa în NLP a început la Centrul pentru Studii Avansate al NLP, fondat de Leslie Cameron-Bandler, unde în perioada 1985-1989 a fost trainer PNL şi din 1986 până în 1989 a fost și proprietarul Centrului. Din 1993 până în prezent, Carl a fost proprietar și director de instruire la NLP Marin din San Rafael, California. Carl călătorește la nivel global, ținând cursuri și predând metodologia inovatoare pe care o numește Transformational NLP, dar principalul său accent continuă să fie lucrul direct cu studenții și clienții. În prezent, acesta predă treizeci şi cinci de weekenduri de antrenament de trei zile pe an, iar în timpul săptămânii lucrează cu cincisprezece până la douăzeci de persoane sau cupluri pe săptămână în cabinetul său privat. Este posibil ca Buchheit să fi predat și mai multe clase și să fi lucrat cu mai mulți clienți personali decât orice antrenor practicant NLP din lume. Ellie Schamber are un doctorat în Istorie Intelectuală și Culturală Europeană la Universitatea din California, la Berkeley. Ea şi-a revizuit doctoratul într-o carte publicată de University Press în 1984. Ulterior, a predat la Universitatea din Arizona, Mississippi State University și Southeastern Louisiana University. A devenit studentă la Carl Buchheit's NLP Marin în 2000 și a continuat să studieze și să practice NLP transformator de atunci. În prezent, locuiește și lucrează în Mill Valley, California. Ea oferă în mod regulat publicului informații despre realitatea spirituală a NLP-ului.

Concluzii ortodoxe asupra mesajului promovat în volum: Trebuie conştientizat faptul că Mişcarea de Dezvoltare a Potenţialului Uman (HPM) face parte dintre cele mai influente şi mai semnificative procedee de dezvoltare personală din arsenalul New Age, atât din România, cât și din restul lumii, la ora actuală. Mesajul HPM este transmis succesiv printr-o serie de conferinţe, 
Recenzie: Carl Buchheit, Eliie Schamber,

Transformational NLP: A New Psychology

programe, workshop-uri, cursuri și seminarii de instruire care înglobează idei specifice grupărilor de tip New Age.

Sub masca mesajului simplist, că omul trebuie să conștientizeze puterile sale nelimitate, ele promovează o serie de teorii și principii care sunt contrare credinței creștine. $\mathrm{Nu}$ în ultimul rând, modalitatea de a transmite acest mesaj conduce, de cele mai multe ori, la cazuri reale de vătămare psihică sau chiar la felurite psihoze. Învăţătura despre potenţa nelimitată a omului, prin sine și prin propriile acțiuni, se opune învăţăturii creștine ortodoxe referitoare la unicitatea persoanei umane în relaţia ei directă cu Dumnezeu.

La rândul său, Programarea Neuro-Lingvistică, prin afirmarea ,ancorelor”, a anumitor experiențe neplăcute sau traumatizante din viața personală, cu scopul de a se curăța de efectele negative ale acestor bariere, poate vătăma emoțional și sufletește persoanele care se expun acestei tehnici. Pentru un creștin ortodox nu poate exista nicio paralelă între NLP şi Taina Sfintei Spovedanii. Este discutabil rezultatul concret al „mărturisirii” publice a propriilor greșeli și eșecuri și în ce măsură această confesiune aduce o vindecare sufletească reală.

\section{Drd. Gheorghe-Vlăduț Rădulescu}

Facultatea de Teologie Ortodoxă ,, Justinian Patriarhul”, Universitatea din București 